\title{
Removal of Chromium(III) from the Waste Solution of an Indian Tannery by Amberlite IR 120 Resin
}

\author{
Pratima Meshram ${ }^{1}$, Sushanta Kumar Sahu ${ }^{1 *}$, Banshi Dhar Pandey ${ }^{1}$, \\ Vinay Kumar ${ }^{1}$, Tilak Raj Mankhand ${ }^{2}$ \\ ${ }^{1}$ Metal Extraction \& Forming Division, CSIR-National Metallurgical Laboratory, Jamshedpur, India \\ ${ }^{2}$ Department of Metallurgical Engineering, IIT BHU, Varanasi, India \\ Email: *sushanta_sk@yahoo.com
}

Received July 12, 2012; revised August 19, 2012; accepted August 29, 2012

\begin{abstract}
The extraction of chromium(III) from a model waste solution and also from a waste solution of an Indian tannery with Amberlite IR 120 resin is described, and the performance of this resin is compared with other similar resins. The parameters that were optimized include effect of mixing time, $\mathrm{pH}$, loading and elution behaviours of chromium(III) for this resin. Sorption of chromium(III) on Amberlite IR 120 followed Freundlich isotherm and Langmuir isotherm model, and the maximum sorption capacity was determined to be $142.86 \mathrm{mg} \mathrm{Cr}(\mathrm{III}) / \mathrm{g}$ of the resin. Higher Freundlich constant $\left(K_{f}\right)$ values (6.30 and 13.46 for aqueous feed of 500 and $1000 \mathrm{ppm} \mathrm{Cr}(\mathrm{III})$ ) indicated strong chemical interaction through ion exchange mechanism of the metal ion with the resin. The kinetic data showed good fit to the Lagergren first order model for extraction of chromium(III). Desorption of chromium(III) from the loaded resin increased with the increase in concentration of eluent $\left(5 \%-20 \% \mathrm{H}_{2} \mathrm{SO}_{4}\right)$. With $20 \%(\mathrm{v} / \mathrm{v})$ sulphuric acid solution $94 \%$ chromium(III) was eluted in three stages. Elution of the $\mathrm{Cr}(\mathrm{III})$ in the column experiments was however, found to be lower $(82 \%)$ than that of the shake flask data. In case of Indian tannery's waste solution, it was observed that almost total chromium was extracted in four stages with Amberlite IR 120.
\end{abstract}

Keywords: Chromium(III); Ion exchange; Amberlite IR 120; Tannery Waste Solution

\section{Introduction}

In recent years, chromium has received considerable attention owing to uses of its compounds in pigments and paints, leather tanning, oxidative dying, electroplating, fungicides, catalysis, refractory materials, glass Industries and various other industrial applications. These industrial processes discharge large quantities of chromium into the environment. Chromium occurs in aqueous systems in the trivalent and hexavalent forms. Out of the two forms, hexavalent chromium is more hazardous to living organisms than the chromium(III). Rapid oxidation of chromium(III) to chromium(VI) state in aquatic and solid wastes situations accounts for mobility of chromium. Therefore, removal and recovery of chromium(III) from industrial wastewater and effluents are critical from both ecological and economic point of view. It may reduce the risk of polluting environment while the recovered compounds of chromium(III) can be reused.

There are around 2500 tanneries in India including Tamilnadu (50\%), West Bengal (20\%) and Uttar Pradesh $(15 \%)$. The other important states for the leather processing are Maharashtra, Andhra Pradesh and Punjab. In-

${ }^{*}$ Corresponding author. dia annually produces around 180 million $\mathrm{m}^{2}$ of leather, which accounts for about $10 \%$ of global production [1]. As leather tanning industry effluent is one of the main sources of chromium pollution in aquatic system and the production of leather is increasing in India, development of a process for the removal of chromium ions is very important for the country. Basic $\mathrm{Cr}(\mathrm{III})$ sulphate is the main chemical used in the tanning process after which the spent tanning solution is discharged with a high concentration of chromium, causing harmful effects to the environment. The consumption of basic chromium salts by the Indian leather industry is about 24,000 tons per annum. Thus, about $2000-3200$ tons of elemental chromium escape into the environment annually from these industries, with a chromium concentration ranging between $2000-5000 \mathrm{mg} / \mathrm{L}$ [2]. These waste solutions are generally diluted and treated to convert $\mathrm{Cr}$ (III) to a hydroxide sludge for disposal [3]. Whilst the treated waste water is allowed to enter to land stream with still higher level of chromium compared to the recommended permissible limit of $2 \mathrm{mg} / \mathrm{L}$. This trend, if not arrested, will certainly lead to a huge material loss as well as creating an ecological imbalance.

A number of methods viz. chemical precipitation [4], 
coagulation [5], adsorption [6], solvent extraction [7], ion exchange [8], biosorption [9], membrane separation [10, $11]$, etc. are available for removal of metal ions from liquid waste streams. Literature survey further shows that ion exchange is one of the most frequently studied and widely applied techniques for the treatment of metalcontaminated wastewater, recovery of metallic substances from such streams, and the regeneration of solutions for recycling [12-16]. This is a promising technique based on adsorption of cations or anions on synthetic resins with essential characteristics of its regeneration after elution. Further, this has two main advantages over its competitor like solvent extraction: mixing and settling arrangements are not required and organic phase losses are completely avoided. Besides, ion exchange is appropriately suited to treat even the low metal ion containing solutions particularly those of waste streams obtained from the processing of low grade materials and effluents.

Several studies considering the chromium removal by ion exchange resins have been reported in the literature. Agrawal et al. [17] have recently reviewed the remediation options for the treatment of chromium containing waste solutions and summarized the possibilities of using different methods including ion exchange. Petruzzelli et al. [18,19] have developed a process, known as IERECHROME (Ion Exchange Recovery of Chromium) for removal, recovery and reuse of chromium(III) from segregated tannery wastewater. The process has the advantage of recovery of almost pure chromium ( $>99 \%$ ) from other interfering metals and organic compounds. Kocaoba and Akcin [20], have studied the removal of chromium(III) and cadmium(II) from aqueous solution using Amberlite IR 120, a strong cation exchange resin. Both batch and continuous ion exchange process for the recovery of chromium(III) from the aqueous chloride solution by using Amberlite IR 120 has been described by Alguacil et al. [21]. Kocaoba and Akcin [22] have also compared the performance of Amberlite IR 120 with two weakly acidic resins, Amberlite IRC 76 and Amberlite IRC 718, and observed that both the weakly acidic resins exhibited better performance than Amberlite IR 120. Recent studies [23-25] have shown that chelating resins could be used for the selective removal and recovery of trivalent chromium. Three chelating ion-exchange resins (Amberlite IRC 748, Diaion CR 11 and Diphonix) were tested [26] for separation of $\mathrm{Cr}$ (III) from industrial effluents produced in hard and decorative electroplating. Efforts are also made to develop newer chelating sorbents with new organic functionalities for recovery of chromium(III) from wastewaters [27-29].

Recently, Sahu et al. [30] studied the removal of chromium(III) from tannery waste solution using a new strongly acidic cation exchange resin, Indion 790. Kinetics and loading capacity of Indion 790 were found to be much better than other reported resins viz. Lewatit S100 [31] and IRN 77 [32], although extraction efficiency suffered after $\mathrm{pH}$ 3.5. In view of the presence of high salt content and various organic substances in the waste tanning solution [33] a detailed investigation on the applicable of Amberlite IR 120 for the removal of chromium(III) from model and actual waste tanning solution of an Indian industry has been reported in the present study. The performance of Amberlite IR 120 has also been compared with other commercially available cation exchange resins of similar type.

\section{Experimental}

In the present study, recovery of chromium from the model tanning solutions containing 500 and 1000 ppm chromium(III) by ion exchange using a macro-porous strongly acidic cation exchange resin derived from sulfonated polystyrene group, Amberlite IR 120 has been used. Amberlite IR 120 manufactured from Rohm and Haas Company Limited (USA), has the physical properties and specifications as given in Table 1. Before experiments, about $20 \mathrm{~g}$ of the resin was washed properly with $200 \mathrm{~mL}$ of distilled water and pre-treated with 50 $\mathrm{mL}$ of $5 \%(\mathrm{v} / \mathrm{v})$ hydrochloric acid for $10 \mathrm{~min}$. The treated resin was again washed properly with distilled water to remove excess $\mathrm{Cl}^{-}$and dried at room temperature for $24 \mathrm{~h}$. The resin was stored in dry condition for experimental work. A synthetic stock solution of $1000 \mathrm{ppm}$ of chromium(III) was prepared by dissolving required amount of $\mathrm{CrCl}_{3} \cdot 6 \mathrm{H}_{2} \mathrm{O}$ in distilled water, and solution of desired concentration was prepared by diluting the stock solution.

To study the extraction of chromium(III) by ion exchange, $50 \mathrm{~mL}$ of the aqueous solution of known concentration and $\mathrm{pH}$ (2.7 which is similar to the waste tannery solution) was equilibrated with weighed amount

Table 1. Properties of Amberlite IR 120 ion exchange resin.

\begin{tabular}{cc}
\hline Parameter & Remarks \\
\hline Ionic form & $\mathrm{H}^{+}$ \\
Functional group & $\mathrm{SO}_{3}^{-}$ \\
Matrix type & Styrene DVB \\
Resin type & Macroporous strong acidic \\
cation & $0.6-0.8$ \\
Particle size (mm) & $45-50$ \\
Moisture $(\%)$ & $120-150$ \\
Max. operating temp. $\left({ }^{\circ} \mathrm{C}\right)$ & $0-14$ \\
pH range & 2.0 \\
\hline
\end{tabular}


$(1.0 \mathrm{~g})$ of dry resin so as to maintain the $\mathrm{A} / \mathrm{R}$ ratio of 50 ( $\mathrm{A}=$ volume of the aqueous feed in $\mathrm{mL}$ and $\mathrm{R}=$ amount of resin in g) unless stated otherwise. The loaded resin was washed thoroughly with distilled water and then chromium was eluted with $50 \mathrm{~mL}$ of sulphuric acid solution of a known strength. All the extraction and elution studies were carried out at $303 \mathrm{~K}$. The raffinate and the eluted solutions were analyzed for chromium concentration by Atomic Absorption Spectrometer (ECIL, India) and the material balance was checked. Sorption isotherms were determined by repeatedly loading the resin with 500 or $1000 \mathrm{ppm}$ chromium solutions for eight and six times, respectively. The extraction data were fitted into different isotherms in order to determine the sorption performance and loading capacity of the resin for chromium(III) ion.

Ion exchange behaviour of Amberlite IR 120 was also investigated by passing chromium(III) solution at a flow rate of $2 \mathrm{~mL} / \mathrm{min}$ over $1.0 \mathrm{~g}$ of this resin packed in a column. Industrial application of the resin was examined and compared by studying the recovery of chromium(III) from the actual tanning waste solution. The tanning waste solution was obtained through Central Leather Research Institute (CLRI), Chennai from a plant situated in Chennai, India. The composition of the waste solution is given in Table 2. The tannery waste solution contains biogenic matter and a large variety of inorganic chemicals and organic contaminants $[33,34]$ such as aliphatic sulfonates, sulphates, aromatic and aliphatic ethoxylates, sulfonated poly-phenols, acrylic acid, fatty acids, dye, proteins, soluble carbohydrates etc.; the organic load of the solution is presented as COD of $4.4 \mathrm{~g} / \mathrm{L}$ and BOD of $2.2 \mathrm{~g} / \mathrm{L}$ (Table 2). The waste tannery solution was diluted 10 times and used for extraction of chromium(III) with Amberlite IR 120.

\section{Results and Discussion}

\subsection{Effect of Mixing Time}

The effect of mixing time on extraction of chromium

Table 2. Composition of the tanning bath solution collected from CLRI, Chennai.

\begin{tabular}{cc}
\hline Constituent & g/L \\
\hline $\mathrm{Cr}(\mathrm{III})$ & 4.57 \\
$\mathrm{Fe}(\mathrm{III})$ & 0.05 \\
$\mathrm{Al}(\mathrm{III})$ & 0.12 \\
$\mathrm{COD}$ & 4.4 \\
$\mathrm{BOD}$ & 2.2 \\
$\mathrm{SO}_{4}^{2-}$ & 12.0 \\
$\mathrm{NaCl}^{2-}$ & 60 \\
$\mathrm{pH}$ & 2.5 \\
\hline
\end{tabular}

from aqueous feeds containing 500 or $1000 \mathrm{ppm} \mathrm{Cr}(\mathrm{III})$ was investigated using Amberlite IR 120 at an initial $\mathrm{pH}$ of 2.7 and $\mathrm{A} / \mathrm{R}=50$. The extraction of chromium(III) increased as the contact time increased and a maximum of $99 \% \mathrm{Cr}$ (III) was extracted in $15 \mathrm{~min}$ from $500 \mathrm{ppm}$ chromium(III) solution, although the major extraction (93\%) was achieved in 5 min time (Figure 1). On the other hand $96 \%$ chromium was extracted in $15 \mathrm{~min}$ and major extraction (90\%) was achieved in $8 \mathrm{~min}$ for 1000 ppm Cr(III) solution. The metal extraction versus time curve is smooth and continuous, leading to saturation indicating that equilibrium is attained on the surface of the resin.

Extraction of chromium is also dependent on initial concentration of the metal in solution. Figure 1 shows that in 15 min extraction of chromium with Amberlite IR 120 was higher $(99 \%)$ for the feed concentration of 500 ppm $\mathrm{Cr}$ (III) as compared to the concentrated solution containing $1000 \mathrm{ppm}$ chromium where extraction was $96 \%$. This is due to the fact that in dilute solution the amount of active sites available in the resin is higher as compared to that of concentrated solutions, and therefore higher level of extraction is observed from the dilute solution

\subsection{Effect of $\mathbf{p H}$}

In order to optimize the $\mathrm{pH}$ for maximum removal efficiency, the experiments were conducted with 500 and $1000 \mathrm{ppm} \mathrm{Cr}(\mathrm{III})$ at $\mathrm{A} / \mathrm{R}$ of 50 and 15 min contact time using Amberlite IR 120 in the $\mathrm{pH}$ range 1.0 - 5.0. The effect of $\mathrm{pH}$ on the extraction of $\mathrm{Cr}(\mathrm{III})$ is presented in Figure 2. Extraction was found to be almost constant in the $\mathrm{pH}$ range $1.0-4.5$ and further increase in $\mathrm{pH}$ caused decrease in chromium extraction. The $\mathrm{pH}$ value of the solution is an important factor that controls the sorption of chromium(III), affecting its uptake on the resins; in general the uptake decreases at higher $\mathrm{pH}$ values [32].

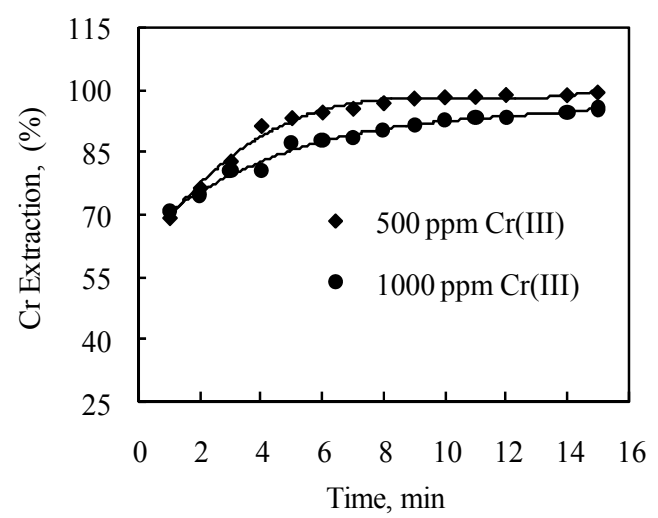

Figure 1. Effect of mixing time on extraction of chromium (III) with Amberlite IR 120. $[\mathrm{Cr}(\mathrm{III})]=500 \mathrm{ppm}, \mathrm{pH}=2.7$, $\mathbf{A} / \mathbf{R}=\mathbf{5 0}$. 


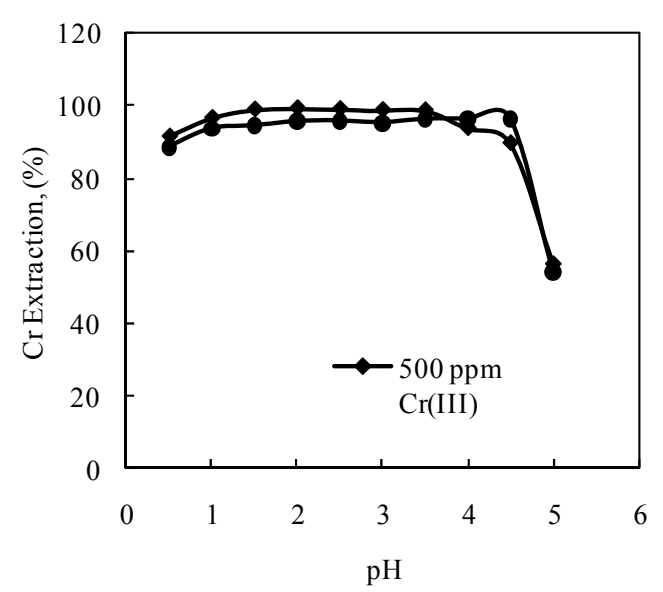

Figure 2. Effect of pH on extraction of chromium(III) with Amberlite IR 120. $[\mathrm{Cr}(\mathrm{III})]=500 \mathrm{ppm}, \mathrm{A} / \mathrm{R}=\mathbf{5 0}$, Contact time $=15 \mathrm{~min}$.

High removal efficiency of chromium by Amberlite IR 120 in the $\mathrm{pH}$ range $1.0-4.5$ can likely to be ascribed to the effect of competitive binding between chromium(III) and hydrogen ions on the surface of the resin. At $\mathrm{pH}<1$, an excess of hydrogen ions can compete effectively with chromium(III) for binding sites, resulting in a lower level of chromium(III) uptake. At $\mathrm{pH}$ values above 4.5 , chromium(III) ions might hydrolyse and precipitate forming the hydroxyl complexes of chromium, $\mathrm{Cr}(\mathrm{OH})_{3}$. Chromium(III) thus showed strong affinity towards the resin in the $\mathrm{pH}$ range 1.0 to 4.5 .

\subsection{Sorption Isotherm}

An adsorption isotherm is used to characterize the equilibria between the amount of adsorbate that accumulates on the adsorbent and the concentration of the dissolved adsorbate. In order to understand the nature of adsorption isotherm of chromium(III) on Amberlite IR $120,1.0 \mathrm{~g}$ of the resin was repeatedly contacted with fresh $500 \mathrm{ppm}$ and also with $1000 \mathrm{ppm}$ chromium(III) solutions. The trend of extraction of chromium(III) by the resin is shown in Figure 3, which indicates that in eight contacts $100 \mathrm{mg}$ chromium(III) is transferred to the resin with $500 \mathrm{ppm}$ chromium(III) solution. Whereas, in case of $1000 \mathrm{ppm} \mathrm{Cr}$ (III) solution, in six contacts 136.7 $\mathrm{mg}$ chromium(III) is transferred to the resin. The data so obtained while repeatedly loading Amberlite IR 120 with chromium(III) were fitted into Freundlich and Langmuir isotherms.

Freundlich model assumes that the uptake or adsorption of metal ions occurs on a heterogeneous surface by monolayer adsorption. The model is described by the following equation:

$$
q=K_{f}\left(C_{e}\right)^{1 / n}
$$

taking $\log$ of Equation (1)

$$
\log q=\frac{1}{n} \log C_{e}+\log K_{f}
$$

The plot (Figure 4) of $\log q$ versus $\log C_{e}$ gave a straight line indicating that the amount of chromium(III) adsorbed on the surface of Amberlite IR 120 depends linearly on the equilibrium chromium(III) concentration in the aqueous solution with a correlation coefficient $\left(\mathrm{R}^{2}\right)$ of 0.988 and 0.985 with a feed concentration of 500 and 1000 ppm $\mathrm{Cr}(\mathrm{III})$ solution respectively. The Freundlich constants $\left(K_{f}\right)$ were found to be 6.30 and 13.46 for 500 and $1000 \mathrm{ppm}$ chromium(III) solution respectively.

According to Langmuir model, uptake of metal ions occurs on a homogeneous surface by monolayer sorption without any interaction with the sorbed ionic species. The model is described by:

$$
q=\frac{\left(q_{m} K_{l} C_{e}\right)}{\left(1+K_{l} C_{e}\right)}
$$

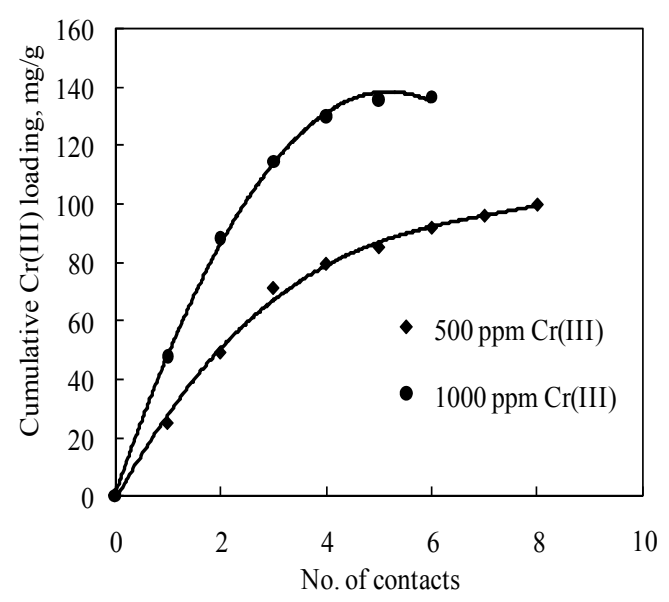

Figure 3. Saturation loading of Amberlite IR 120 with 500 ppm chromium(III) solution. $\mathbf{p H}=2.7$, Contact time $=15$ $\min , \mathbf{A} / \mathbf{R}=\mathbf{5 0}$.

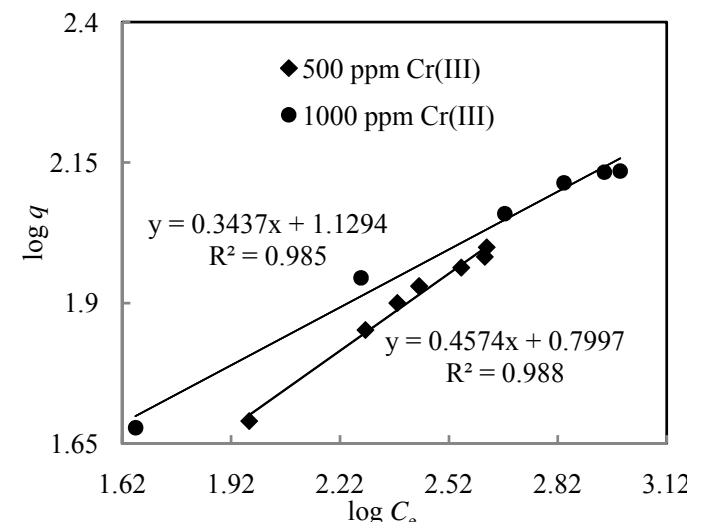

Figure 4. Freundlich isotherm for sorption of chromium(III) with Amberlite IR 120. 
rearranging Equation (3)

$$
\frac{1}{q}=\frac{1}{\left(q_{m} K_{l} C_{e}\right)}+\frac{1}{q_{m}}
$$

The plot (Figure 5) of $1 / q$ versus $1 / C_{e}$ shows that $1 / q$ depends linearly with $1 / C_{e}$ with a correlation coefficient of 0.996 and 0.990 for 500 and 1000 ppm Cr(III) solution respectively. Langmuir constants $\left(K_{l}\right)$ were found to be 0.006 and 0.011 for aqueous feed of $500 \mathrm{ppm}$ and 1000 ppm chromium(III) solution respectively (Table 3). From the Langmuir model, loading capacity of Amberlite IR 120 for chromium(III) was also determined and found to be $142.86 \mathrm{mg} / \mathrm{g}$ of resin. Loading capacity of Amberlite IR 120 was found to be higher in the present investigation than that of other resins of similar characteristics (Table 4) because of higher metal concentration in the aqueous solution.

The plots depicted in Figures 4 and 5 show that the equilibrium adsorption data fitted well into the linear Langmuir and Freundlich isotherms. However, higher Freundlich constant values $\left(K_{f}=6.30\right.$ and 13.46) and values of $n$ (2.18 and 2.92) between 1 and 10 indicated strong chemical interaction between the resin and chromium(III) [35], this also showed that the loading of metal on to the resin surface followed ion exchange mechanism rather than the adsorption mode.

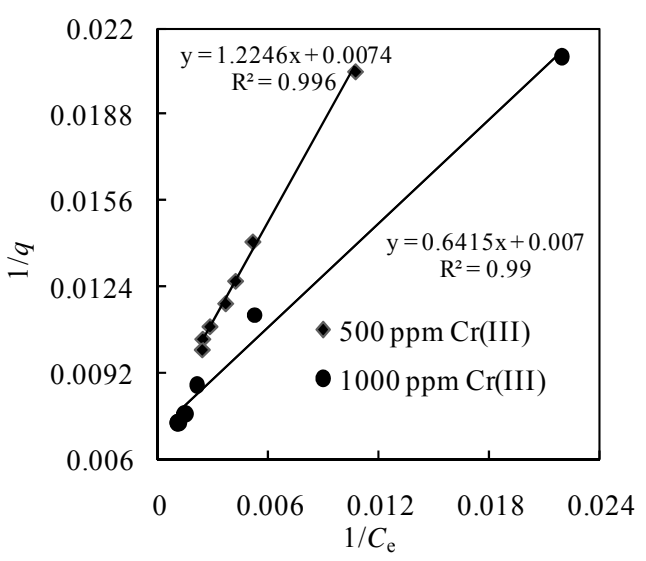

Figure 5. Langmuir isotherm for sorption of chromium(III) with Amberlite IR 120.

Table 3. Physical constants obtained for Freundlich and Langmuir isotherms.

\begin{tabular}{cccccc}
\hline \multirow{2}{*}{$\begin{array}{c}\text { Feed } \\
\text { concentration }\end{array}$} & \multicolumn{2}{c}{ Freundlich isotherm } & \multicolumn{2}{c}{$\begin{array}{c}\text { Langmuir } \\
\text { Isotherm }\end{array}$} \\
\cline { 2 - 6 } & $R^{2}$ & $K_{f}$ & $n$ & $R^{2}$ & $K_{l}$ \\
\hline 500 ppm Cr(III) & 0.988 & 6.30 & 2.18 & 0.996 & 0.006 \\
1000 ppm & 0.985 & 13.46 & 2.92 & 0.990 & 0.011 \\
\hline Cr(III) & & & & & \\
\hline
\end{tabular}

\subsection{Kinetics of Extraction}

To understand the sorption mechanism of chromium(III) on Amberlite IR 120, the kinetic data were fitted into Lagergren first order model [36]:

$$
\log \left(q_{e}-q_{t}\right)=\log q_{e}-\frac{K_{l}}{2.303} t
$$

where all the terms have usual meaning as defined in the nomenclature section. From Figure 6 on $\log \left(q_{e}-q_{t}\right)$ versus time, the first order rate constant value determined from the slope of straight line, for exchange of chromium(III) ions from an aqueous feed of $500 \mathrm{ppm}$ to Amberlite IR 120 was found to be $0.297 \mathrm{~min}^{-1}$ with correlation coefficient $\left(R^{2}\right)$ of around 0.978 , whilst with 1000 ppm Cr(III) feed solution, the first order rate constant for exchange of chromium(III) ions was calculated to be $0.129 \mathrm{~min}^{-1}$ with correlation coefficient $\left(R^{2}\right)$ of about 0.970 . The low values of rate constants further indicate that the extraction process is controlled by internal particle diffusion of sorbed chromium(III) species on the resins as discussed below.

Different mechanisms and steps in ion-exchange phenomena can control the kinetics. Four major rate limiting steps are generally cited. Out of these first two are mass transfer resistance steps comprising of the mass transfer of solute from solution to the boundary film initially and then mass transfer of metal ions from boundary film to the surface. After mass transfer steps sorption and ion exchange of ions onto sites takes place and finally internal diffusion of solute takes place. The external mass transfer resistance steps are neutralized with the homogeneity of the solution, and the third step is fast. Therefore, internal particle diffusion of sorbed chromium(III) limits the process.

As reported by Ho and McKay [37], the sorption will follow the first order kinetics unless the experimental data are much scattered or deviated with time. In the

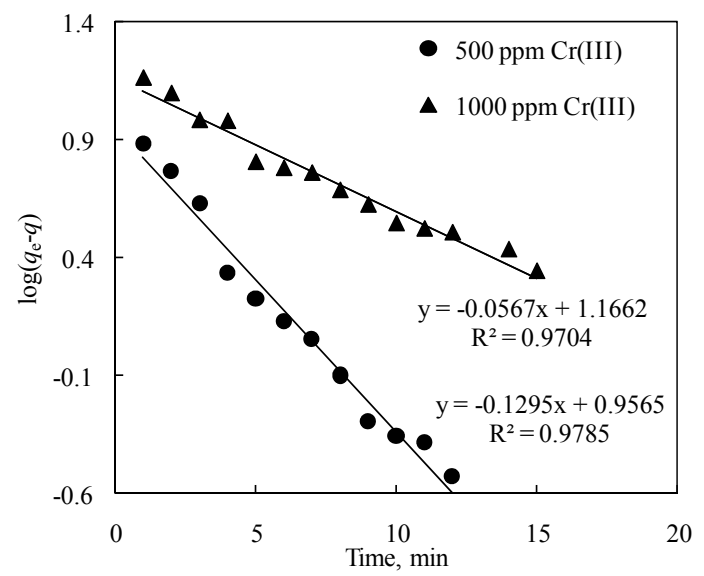

Figure 6. First order kinetics for extraction of chromium (III) by ion exchange withAmberlite IR 120. 
Table 4. Comparisons of performances of different resins used for chromium(III) extraction.

\begin{tabular}{|c|c|c|c|c|c|c|c|c|c|}
\hline $\begin{array}{c}\text { Ion } \\
\text { Exchanger }\end{array}$ & Nature of resin & $\begin{array}{c}\text { A/R } \\
(\mathrm{mL} / \mathrm{g})\end{array}$ & $\begin{array}{l}\text { Initial } \\
\text { Conc. } \\
\text { (mg/L) }\end{array}$ & $\mathbf{p H}$ & $\begin{array}{l}\mathrm{Cr}(\mathrm{III}) \\
\text { removal } \\
\text { efficiency }\end{array}$ & Wastewater & $\begin{array}{l}\text { Loading } \\
\text { Capacity } \\
(\mathrm{mg} / \mathrm{g})\end{array}$ & Highlights & References \\
\hline Lewatit S 100 & $\begin{array}{l}\text { Sulfonic acid group } \\
\text { with cross linked } \\
\text { polystyrene matrix }\end{array}$ & 300 & 52 & 3.5 & $99 \%$ & $\mathrm{CrCl}_{3}$ & 20.3 & $\begin{array}{l}\text { Sorption followed Langmuir } \\
\text { isotherm and first-order } \\
\text { reversible kinetics. }\end{array}$ & {$[31]$} \\
\hline $\begin{array}{c}\text { Amberlite IR } \\
120\end{array}$ & $\begin{array}{l}\text { Sulfonic acid group } \\
\text { with Styrene-DVB } \\
\text { polymer matrix }\end{array}$ & 100,000 & 10 & 5 & $\begin{array}{l}94.27 \% \\
87.61 \% \text { in } \\
\left(\mathrm{H}^{+}\right) \text {form }\end{array}$ & $\begin{array}{c}{\left[\mathrm{Cr}_{4}\left(\mathrm{SO}_{4}\right)_{5}\right.} \\
\left.\quad(\mathrm{OH})_{2}\right]\end{array}$ & $\begin{array}{c}2.53\left(\mathrm{Na}^{+}\right), \\
2.19\left(\mathrm{H}^{+}\right)\end{array}$ & $\begin{array}{l}\text { Amberlite IRC } 76 \text { and } 718 \\
\text { weakly acidic resins showed } \\
\text { better performance than } \\
\text { Amberlite IR } 120 \text { for recovery } \\
\text { of } \mathrm{Cr}(\mathrm{III}) \text { in } \mathrm{Na}^{+} \text {form. Elution } \\
\text { was achieved with } 10 \% \mathrm{HCl} \text { at } \\
5 \mathrm{BV} \mathrm{h}^{-1} \text { flow rate. }\end{array}$ & {$[22]$} \\
\hline $\begin{array}{c}\text { Amberlite IR } \\
120\end{array}$ & $\begin{array}{l}\text { Sulfonic acid group } \\
\text { with Styrene-DVB } \\
\text { polymer matrix }\end{array}$ & 10,000 & 20 & 5.5 & $\begin{array}{c}68.24 \% \mathrm{Cr} \text {, } \\
90.8 \% \mathrm{Cd} \text { in } \\
\mathrm{Na}^{+} \text {form and } \\
72.41 \% \mathrm{Cr} \text {, } \\
81.1 \% \mathrm{Cd} \text { in } \\
\mathrm{H}^{+} \text {form }\end{array}$ & $\begin{array}{l}{\left[\mathrm{Cr}_{4}\left(\mathrm{SO}_{4}\right)_{5}\right.} \\
\quad(\mathrm{OH})_{2} \\
{\left[\mathrm{Cd}\left(\mathrm{NO}_{3}\right)_{2}\right.} \\
\left.\quad 4 \mathrm{H}_{2} \mathrm{O}\right]\end{array}$ & $\begin{array}{c}2.53 \\
\left(\mathrm{Na}^{+}\right) \\
2.19\left(\mathrm{H}^{+}\right)\end{array}$ & $\begin{array}{l}\text { Cadmium adsorption was } \\
\text { much higher than chromium } \\
\text { in } \mathrm{Na}^{+} \text {form. }\end{array}$ & {$[20]$} \\
\hline $\begin{array}{c}\text { Amberlite IR } \\
120\end{array}$ & $\begin{array}{l}\text { Sulfonic acid group } \\
\text { with Styrene-DVB } \\
\text { polymer matrix }\end{array}$ & 200 & 500 & 0.92 & - & $\mathrm{CrCl}_{3}$ & 67.7 & $\begin{array}{l}\text { Followed Langmuir isotherm, } \\
\text { and film-diffusion controlled } \\
\text { kinetics. }\end{array}$ & [21] \\
\hline IRN 77 & $\begin{array}{l}\text { Sulfonic acid group } \\
\text { with polystyrene } \\
\text { DVB matrix }\end{array}$ & 200 & 100 & 2.7 & $>95 \%$ & $\begin{array}{l}\mathrm{Cr}\left(\mathrm{NO}_{3}\right)_{3} / \text { chromi } \\
\text { um containing } \\
\text { synthetic } \\
\text { primary coolant } \\
\text { water }\end{array}$ & 35.4 & $\begin{array}{c}\text { Followed Freundlich } \\
\text { adsorption isotherm. } \\
\text { Adsorption of } \mathrm{Co}, \mathrm{Cr} \text { and } \mathrm{Ni} \\
\text { followed the first order kinetic } \\
\text { model. }\end{array}$ & {$[32]$} \\
\hline SKN 1 & $\begin{array}{l}\text { Sulfonic acid } \\
\text { group }\end{array}$ & 200 & 100 & 2.7 & $>95 \%$ & $\mathrm{Cr}\left(\mathrm{NO}_{3}\right)_{3}$ & 46.3 & $\begin{array}{l}\text { Followed Freundlich adsorp- } \\
\text { tion isotherm. Adsorption of } \\
\mathrm{Co}, \mathrm{Cr} \text { and Ni followed the } \\
\text { first order kinetic model. }\end{array}$ & {$[32]$} \\
\hline Indion 790 & $\begin{array}{l}\text { Styrene DVB with } \\
\text { sulfonic acid } \\
\text { groupmacro-porous } \\
\text { strongly acidic } \\
\text { cation exchange } \\
\text { resin of sulfonated } \\
\text { polystyrene group }\end{array}$ & 50 & 500 & 2.74 & $92 \%$ & $\mathrm{CrCl}_{3}$ & 86.9 & $\begin{array}{l}\text { Followed Freundlich isotherm } \\
\text { and first order kinetics. With } \\
20 \% \text { sulfuric acid solution } \\
89 \% \text { Cr(III) was eluted in two } \\
\text { stages. }\end{array}$ & {$[30]$} \\
\hline $\begin{array}{c}\text { Amberlite IR } \\
120\end{array}$ & $\begin{array}{l}\text { Sulfonic acid group } \\
\text { with Styrene DVB } \\
\text { matrix }\end{array}$ & 50 & 500 & 2.7 & $99 \%$ & $\mathrm{CrCl}_{3}$ & 142.86 & $\begin{array}{l}\text { Sorption followed Freundlich } \\
\text { isotherm and first-order } \\
\text { kinetics. With } 20 \% \text { sulphuric } \\
\text { acid solution } 94 \% \text { Cr(III) was } \\
\text { eluted in three stages. }\end{array}$ & $\begin{array}{c}\text { Present } \\
\text { work }\end{array}$ \\
\hline
\end{tabular}

present study, the kinetic plot (Figure 6) with time had no deviation and showed good fit (correlation coefficient $\geq 0.97)$ to the Lagergren first order model for extraction of chromium(III).

\subsection{Desorption of Chromium(III)}

Desorption studies help to recover the metals from the loaded resin. The reliability of the ion exchange process strongly depends on the regeneration efficiency of the exchanger. In fact, if a resin is characterized by high selectivity but low desorption capacity, the overall process is then considered less attractive. Desorption of chromium(III) from the loaded Amberlite IR 120 with different concentration of sulfuric acid solution was also studied and the results are given in Table $\mathbf{5}$. As can be 
seen the elution of $\mathrm{Cr}$ (III) showed increasing trend with increase in acid concentration from $5 \%$ to $15 \%(\mathrm{v} / \mathrm{v})$ in the first stage, although the overall elution in 3-stages was almost the same. A maximum of $94 \%$ chromium(III) elution was achieved with $20 \%(\mathrm{v} / \mathrm{v})$ sulfuric acid solution in three stages. The incomplete elution of chromium(III) from the loaded resins may be attributed to the tendency of formation of hydrolysis product such as $\mathrm{Cr}(\mathrm{OH}) \mathrm{SO}_{4}$ which is difficult to elute under normal conditions [32].

\subsection{Extraction of Chromium(III) in Column}

Extraction of chromium(III) by Amberlite IR 120 in a continuous mode was also studied. The aqueous solution of $500 \mathrm{ppm} \mathrm{Cr}$ (III) at $\mathrm{pH} 2.7$ was passed through a small column containing $1.0 \mathrm{~g}$ of resin $(0.9 \mathrm{~mL}$ volume in the column) at a flow rate of $2.0 \mathrm{~mL} / \mathrm{min}$. The plot (Figure 7) of $C_{r} / C_{o}$ versus bed volume shows a breakthrough of $\mathrm{Cr}$ (III) after 100 bed volumes for the resin. Amberlite IR 120 gets saturated after 300 bed volume i.e. after passage of $270 \mathrm{~mL}$ of the solution. Saturation loading of $110 \mathrm{mg}$ $\mathrm{Cr}$ (III)/g Amberlite IR 120 was obtained, which is only slightly lower than the maximum loading capacity determined from the isotherm. Larger scale column test with slower flow rates would achieve proper raffinate concentration, breakthrough points and maximum metal loading.

Table 5. Elution of chromium(III) from loaded Amberlite IR 120 resin.

\begin{tabular}{ccccc}
\hline $\mathbf{H}_{2} \mathbf{S O}_{4}$ & \multicolumn{4}{c}{ Chromium(III) elution (\%) } \\
\cline { 2 - 5 }$(\%)$ & Stage-I & Stage-II & Stage-III & Total \\
\hline 5 & 57.61 & 20.0 & 9.53 & 87.14 \\
10 & 66.84 & 15.11 & 3.85 & 85.8 \\
15 & 71.56 & 12.42 & 2.76 & 86.74 \\
20 & 73.53 & 16.19 & 4.61 & 94.33 \\
\hline
\end{tabular}

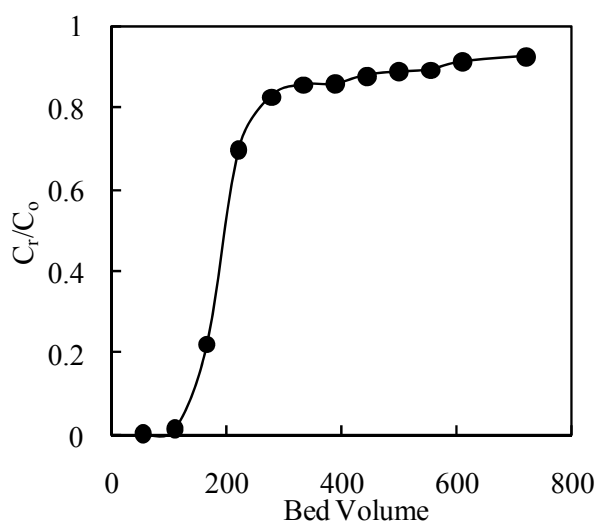

Figure 7. Extraction of chromium(III) with Amberlite IR 120 in column. $\operatorname{Resin}=1.0 \mathrm{~g},[\mathrm{Cr}(\mathrm{III})]=500 \mathrm{ppm}, \mathrm{pH}=\mathbf{2 . 7}$, flow rate $2.0 \mathrm{~mL} / \mathrm{min}$.
When the metal loaded Amberlite IR 120 in the column was eluted with $20 \%(\mathrm{v} / \mathrm{v}) \mathrm{H}_{2} \mathrm{SO}_{4}$ at a flow rate of $2.0 \mathrm{~mL} / \mathrm{min}$, only $82 \%$ chromium(III) was recovered after passing $200 \mathrm{~mL}$ of eluent. However, immediate elution at a slow flow rate after loading may improve the recovery.

\subsection{Recovery of Chromium(III) from Tannery Waste Solution}

A tannery waste solution containing $4.58 \mathrm{~g} / \mathrm{L}$ chromium(III) and small quantities of aluminium and iron, and other constituents obtained through Central Leather Research Institute (CLRI), Chennai, India, was used to establish the process for industrial application of Amberlite IR 120. The discharge limit of chromium, prescribed by Central Pollution Control Board (CPCB), India is 2 ppm for streams [38]. In order to achieve this discharge level for chromium(III), 10 times diluted waste tannery solution was contacted with Amberlite IR 120 at pH 2.7, $\mathrm{A} / \mathrm{R}$ ratio of 50 and a mixing time of $15 \mathrm{~min}$. The raffinate obtained was again contacted with fresh resin. About $83 \%$ chromium(III) was extracted (Figure 8) in the first stage itself and in fourth stage the raffinate with trace amount $(0.022 \mathrm{ppm})$ of chromium(III) was obtained, which was found to be safe for discharge. The efficiency of the resin towards the removal of chromium from the model chromium solution is found to be higher than that of actual tannery waste solution. This may be attributed to the presence of other species/impurities including metal ions present in tannery waste water which may interfere in the ion exchange process. Elution of chromium(III) from loaded resins with $20 \% \mathrm{H}_{2} \mathrm{SO}_{4}$ was also studied and $90 \%$ chromium(III) elution was observed from the loaded Amberlite IR 120 in two stages.

\subsection{A Comparative Performance of Amberlite IR 120 and Other Resins for Removal of Chromium(III) from Waste Solutions}

The extraction behavior of Amberlite IR 120 for chromium(III) from a model waste solution and also from a waste tanning solution has been compared with that of another resin, Indion 790, which was used in our previous work [30]. Both the resins showed similar extraction behaviour towards chromium(III) from a model solution containing $500 \mathrm{ppm}$ chromium(III) at $\mathrm{pH}$ 2.7. A maximum of $99 \%$ and $92 \%$ chromium(III) was recovered with Amberlite IR 120 and Indion 790, respectively in 12 min time.

In comparison, the kinetics of adsorption of chromium(III) with Amberlite IR 120 was faster than that of Indion 790. Both the resins showed constant chromium(III) extraction in the $\mathrm{pH}$ range $1.0-3.5$. Beyond $\mathrm{pH}$ 3.5 extraction of chromium(III) with Indion 790 drastically 


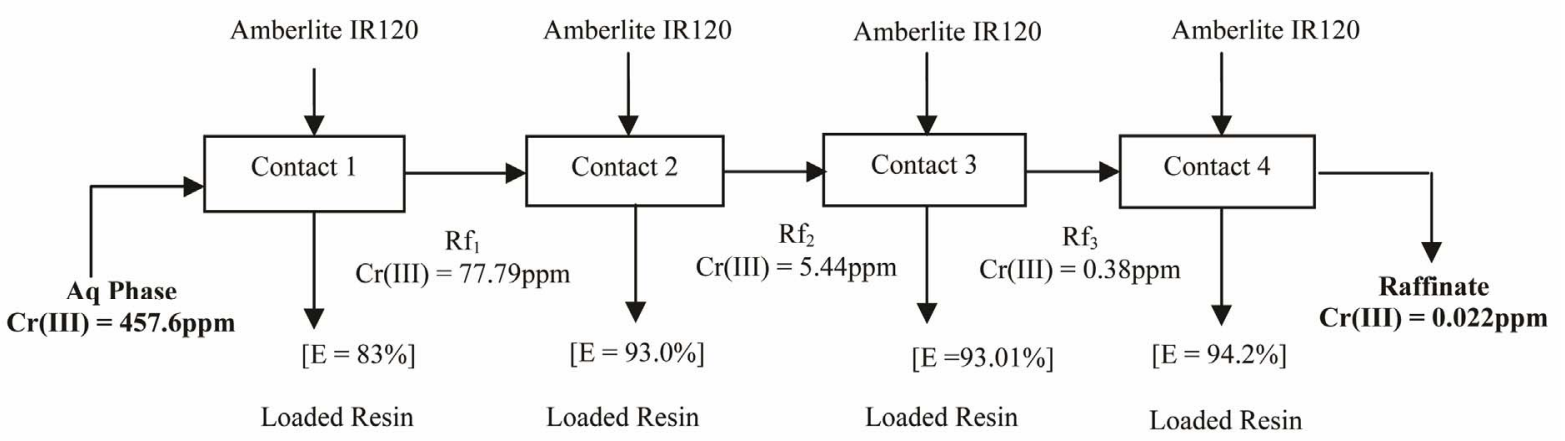

Figure 8. Extraction of chromium(III) from the diluted waste solution of tannery by Amberlite IR 120. Aq. Feed = 457.6 ppm $\mathrm{Cr}(\mathrm{III})$, Initial $\mathbf{p H}=\mathbf{2 . 7}, \mathrm{A} / \mathrm{R}=50, \mathrm{Rf}_{1-4}=$ Raffinate in different contacts, $\mathrm{E}=\%$ extraction of $\mathrm{Cr}(\mathrm{III})$.

decreased from $92 \%$ to $76 \%$ whereas, Amberlite IR 120 was effective even up to $4.5 \mathrm{pH}$. Extraction of $\mathrm{Cr}$ (III) from the tannery waste solution (458 $\mathrm{ppm}^{\mathrm{Cr}^{3+}}$ ) was found to be $99.9 \%$ and $95 \%$ with Amberlite IR 120 and Indion 790 in 3 stages at the aqueous feed pH of 2.7.

Sorption of chromium(III) on Amberlite IR 120 and Indion 790 followed Freundlich isotherm. The higher Freundlich constant $\left(K_{f}\right)$ values such as 6.30 and 8.57 respectively indicated strong chemical interaction of the metal ion with the resins. The Amberlite IR 120 showed higher loading capacity than that of Indion 790 with 500 ppm chromium(III) feed. Both the resin follows the first order kinetic model for extraction of chromium(III). Desorption of chromium(III) from the loaded resins increased with the increase in concentration of eluant $(5 \%$ $20 \% \mathrm{H}_{2} \mathrm{SO}_{4}$ ). With $20 \%(\mathrm{v} / \mathrm{v})$ sulfuric acid solution $94 \%$ chromium(III) was eluted from loaded Indion 790 in two stages, and from loaded Amberlite IR 120, 94\% chromium(III) was eluted in three stages.

Comparative data from some ion exchange studies for chromium(III) are further summarised in Table 4. A comparison between these resins showed that all the resins effectively removed $\mathrm{Cr}$ (III) from the wastewaters. Lewatit S 100 also showed higher chromium removal efficiency $(99 \%)$ from a chloride solution due to the low metal ion concentration used. The removal efficiency as well as loading capacity of Amberlite IR 120 used in the present work even at lower $\mathrm{pH}$ of 2.7 was found to be higher than that of the other similar resins as given in Table 4.

\section{Conclusion}

Amberlite IR 120 - a strong acidic cation exchanger has been used for the extraction of chromium(III) from the tanning waste solution. Different process parameters such as $\mathrm{pH}$ of the feed solution, sorption of metal, kinetics of extraction, elution of metal etc. have been optimized using this resin. When a model solution containing 500 ppm chromium(III) was contacted with Amberlite IR
120 , about $99 \%$ chromium was extracted in 15 min at $\mathrm{pH}$ 2.7 and $\mathrm{A} / \mathrm{R}$ ratio of 50 .Sorption of chromium(III) on Amberlite IR 120 followed Freundlich isotherm model, and the maximum sorption capacity determined was $142.86 \mathrm{mg} / \mathrm{g}$ of the resin. Higher Freundlich constant $\left(K_{f}\right)$ values (6.30 and 13.46) indicated strong chemical interaction of the metal ion with the resin which also showed extraction of $\mathrm{Cr}$ (III) by ion exchange mechanism rather than surface adsorption. The kinetics of the sorption of chromium by the resin followed the first order kinetics. A $20 \%(\mathrm{v} / \mathrm{v})$ sulphuric acid solution gave maximum elution $(94 \%)$ of $\mathrm{Cr}(\mathrm{III})$ from the loaded resin in three stages when treated for $15 \mathrm{~min}$ in each case. Study in column showed breakthrough at 100 bed volume from an aqueous feed of $500 \mathrm{ppm} \mathrm{Cr}$ (III) with a loading of $110 \mathrm{mg}$ $\mathrm{Cr}^{3+} / \mathrm{g}$ of the resin. Incomplete desorption of the loaded metal may be attributed to the formation of hydrolysis products of chromium which are difficult to elute under normal conditions. Almost all chromium can be extracted from a diluted tannery waste solution in four stages, though $90 \% \mathrm{Cr}(\mathrm{III})$ was eluted with $20 \%$ (v/v) sulphuric acid in two stages. The process has a potential for large scale trials to treat the waste tannery solution.

\section{Acknowledgements}

Authors are thankful to the Director, CSIR-National Metallurgical Laboratory, Jamshedpur, India for giving permission to publish the paper. Thanks are also due to Dr. B. U. Nair, CLRI, Chennai for providing solution from a tannery. The financial support received from Planning Commission, Govt. of India through Council of Scientific \& Industrial Research (CSIR) New Delhi under $10^{\text {th }}$ five year plan is gratefully acknowledged.

\section{REFERENCES}

[1] CPCB, "Recovery of Better Quality Reusable Salt from Soak Liquor of Tanneries in Solar Evaporation Pans," Central Pollution Control Board (CPCB) Ministry of Environment \& Forests Control of Urban Pollution Series: 
Cups/2009-10, 2009

[2] P. Chandra, S. Sinha and U. N. Rai, "Bioremediation of Cr from Water and Soil by Vascular Aquatic Plants," In: E. L. Kruger, T. A. Anderson and J. R. Coats, Eds., Phytoremediation of Soil and Water Contaminants, ACS Symposium Series \#664, American Chemical Society, Washington DC, 1997, pp. 274-282.

[3] B. D. Pandey, G. Cote and D. Bauer, "Extraction of Chromium(III) from Spent Tanning Baths," Hydrometallurgy, Vol. 40, No. 3, 1996, pp. 343-357. doi:10.1016/0304-386X(95)00006-3

[4] Q. Chen, Z. Luo, C. Hills, G. Xue and M. Tyrer, "Precipitation of Heavy Metals from Wastewater Using Simulated Flue Gas: Sequent Additions of Fly Ash, Lime and Carbon Dioxide," Water Research, Vol. 43, No. 10, 2009, pp. 2605-2614. doi:10.1016/j.watres.2009.03.007

[5] P. D. Johnson, P. Girinathannair, K. N. Ohlinger, S. Ritchie, L. Teuber and J. Kirby, "Enhanced Removal of Heavy Metals in Primary Treatment Using Coagulation and Flocculation," Water Environment Research, Vol. 80, No. 5, 2008, pp. 472-479.

[6] S. Santosa, D. Siswanta, S. Sudiono and R. Utarianingrum, "Chitin-Humic Acid Hybrid as Adsorbent for $\mathrm{Cr}$ (III) in Effluent of Tannery Wastewater Treatment," Applied Surface Science, Vol. 254, No. 23, 2008, pp. 7846-7850. doi:10.1016/j.apsusc.2008.02.102

[7] S. K. Sahu, V. K. Verma, D. Bagchi, V. Kumar and B. D. Pandey, "Recovery of Chromium(VI) from Electroplating Effluent by Solvent Extraction with Tri-n-Butyl Phosphate," Indian Journal of Chemical Technology, Vol. 15, No. 4, 2008, pp. 397-402.

[8] S. Verbych, N. Hilal, G. Sorokin and M. C. Leaper, "Ion Exchange Extraction of Heavy Metal Ions from Wastewater," Separation Science and Technology, Vol. 39, No. 9, 2004, pp. 2031-2040. doi:10.1081/SS-120039317

[9] G. Zupancic and A. Jemec, "Anaerobic Digestion of Tannery Waste: Semi-Continuous and Anaerobic Sequencing Batch Reactor Processes," Bioresource Technology, Vol. 101, No. 1, 2010, pp. 26-33. doi:10.1016/j.biortech.2009.07.028

[10] M. Pazouki and A. Moheb, "An Innovative Membrane Method for the Separation of Chromium Ions from Solutions Containing Obstructive Copper Ions," Desalination, Vol. 274, No. 1-3, 2011, pp. 246-254.

[11] C. Justina, M. Elsa, P. Ana, L. Ana, S. Luis and N. Maria, "Membrane-Based Treatment for Tanning Wastewaters," Canadian Journal of Civil Engineering, Vol. 36, No. 2, 2009, pp. 356-362. doi:10.1139/S08-053

[12] T. A. Kurniawan, Y. S. C. Gilbert, W. H. Lo and S. Babel, "Physico-Chemical Treatment Techniques for Wastewater Laden with Heavy Metals," Chemical Engineering Journal, Vol. 118, No. 1-2, 2006, pp. 83-98. doi:10.1016/j.cej.2006.01.015

[13] I. Lee, Y. Kuan and J. Chern, "Equilibrium and Kinetics of Heavy Metal Ion Exchange," Journal of Chinese Institute of Chemical Engineers, Vol. 38, No. 1, 2007, pp. 7184. doi:10.1016/j.jcice.2006.11.001

[14] J. S. Kentish and G. W. Stevens, "Innovations in Separa- tion Technology for the Recycling and Reuse of Liquid Waste Streams," Chemical Engineering Journal, Vol. 84, No. 2, 2001, pp. 149-159. doi:10.1016/S1385-8947(01)00199-1

[15] S. Yalcin, R. Apak, J. Hizal and H. Afsar, "Recovery of Copper(II) and Chromium(III) from Electroplating Industry Wastewater by Ion Exchange," Separation Science and Technology, Vol. 36, No. 10, 2001, pp. 2181-2196. doi:10.1081/SS-100105912

[16] J. A. S. Tenorio and D. C. R. Espinosa, "Treatment of Chromium Plating Process Effluents with Ion Exchange Resins," Waste Management, Vol. 21, No. 7, 2001, pp. 637-642. doi:10.1016/S0956-053X(00)00118-5

[17] A. Agrawal, V. Kumar and B. D. Pandey, "Remediation Options for the Treatment of Electroplating and Leather Tanning Effluent Containing Chromium: A Review," Mineral Processing and Extractive Metallurgy Review, Vol. 27, No. 2, 2006, pp. 99-130. doi:10.1080/08827500600563319

[18] D. Petruzzelli, R. Passino, M. Santori and G. Tiravanti, "Industrial Waste Management, the Case of the Tannery Industry in Chemical Water and Wastewater Treatment III," Springer-Verlag, Berlin, 1994.

[19] D. Petruzzelli, R. Passino and G. Tiravanti, "Ion Exchange Process for Chromium Removal and Recovery from Tannery Wastes," Industrial Engineering and Chemical Research, Vol. 34, 1995, pp. 2612-2617. doi:10.1021/ie00047a009

[20] S. Kocaoba and G. Akcin, "Removal of Chromium(III) and Cadmium(II) from Aqueous Solutions," Desalination, Vol. 180, No. 1-3, 2005, pp. 151-156. doi:10.1016/j.desal.2004.12.034

[21] F. J. Alguacil, M. Alonso and L. J. Lozano, "Chromium(III) Recovery from Waste Acid Solution by Ion Exchange Processing Using Amberlite-IR 120 Resin: Batch and Continuous Ion Exchange Modeling," Chemosphere, Vol. 57, No. 8, 2004, pp. 789-793. doi:10.1016/j.chemosphere.2004.08.085

[22] S. Kocaoba and G. Akcin, "Removal and Recovery of Chromium and Chromium Speciation with MINTEQA2," Talanta, Vol. 57, No. 1, 2002, pp. 23-30. doi:10.1016/S0039-9140(01)00677-4

[23] N. Kabay, N. Gizli, M. Demircioglu, M. Yuksel, A. Jyo, K. Yamabe and T. Shuto, "Cr(III) Removal by Macroreticular Chelating Ion Exchange Resins," Chemical Engineering Communications, Vol. 190, No. 5-8, 2003, pp. 813-822. doi:10.1080/00986440302114

[24] S. A. Cavaco, S. L. Fernandes, M. M. Quina and L. M. G. Ferreira, "Removal of Chromium from Electroplating Industry Effluents by Ion-Exchange Resins," Journal of Hazardous Materials, Vol. 144, No. 3, 2007, pp. 634-638. doi:10.1016/i.jhazmat.2007.01.087

[25] S. Fernandes, S. A. Cavaco, M. J. Quina and L. M. G. Ferreira, "Selective Separation of Chromium(III) from Electroplating Effluents by Ion-Exchange Processes," Proceedings of European Congress of Chemical Engineering (ECCE-6)," Copenhagen, 2007.

[26] S. A. Cavaco, S. Fernandes, C. M. Augusto, M. J. Quina and L. M. G. Ferreira, "Evaluation of Chelating Ion-Ex- 
change Resins for Separating Cr(III) from Industrial Effluents," Journal of Hazardous Materials, Vol. 169, No. 1-3, 2009, pp. 516-523. doi:10.1016/j.jhazmat.2009.03.129

[27] S. Pramanik, S. Dey and P. Chattopadhyay, "A New Chelating Resin Containing Azophenolcarboxylate Functionality: Synthesis, Characterization and Application to Chromium Speciation in Wastewater," Analytica Chimica Acta, Vol. 584, No. 2, 2007, pp. 469-476. doi:10.1016/j.aca.2006.11.041

[28] P. Chattopadhyay, C. Sinha and D. K. Pal, "Preparation and Properties of a New Chelating Resin Containing Imadazolylazo Groups," Fresenius' Journal of Analytical Chemistry, Vol. 357, No. 4, 1997, pp. 368-372.

[29] F. Gode and E. Pehlivan, "A Comparative Study of Two Chelating Ion-Exchange Resins for the Removal of Chromium (III) from Aqueous Solution," Journal of Hazardous Materials, Vol. 100, No. 1-3, 2003, pp. 231-243. doi:10.1016/S0304-3894(03)00110-9

[30] S. K. Sahu, P. Meshram, B. D. Pandey, V. Kumar and T. R. Mankhand, "Removal of Chromium(III) by Cation Exchange Resin, Indion 790 for Tannery Waste Treatment," Hydrometallurgy, Vol. 99, No. 3-4, 2009, pp. 170-174. doi:10.1016/j.hydromet.2009.08.002

[31] F. Gode and E. Pehlivan, "Removal of Chromium (III) from Aqueous Solutions Using Lewatit S 100: The Effect of $\mathrm{pH}$, Time, Metal Concentration and Temperature," Journal of Hazardous Materials, Vol. 136, No. 2, 2006, pp. 330-337. doi:10.1016/j.jhazmat.2005.12.021

[32] S. Rengaraj, K. H. Yeon and S. H. Moon, "Removal of
Chromium from Water and Wastewater by Ion Exchange Resins," Journal of Hazardous Materials, Vol. 87, No. 1-3, 2001, pp. 273-287. doi:10.1016/S0304-3894(01)00291-6

[33] M. Murugananthan, G. BhaskarRaju and S. Prabhakar, "Separation of Pollutants from Tannery Effluents by Electro Flotation," Separation and Purification Technology, Vol. 40, No. 1, 2004, pp. 69-75. doi:10.1016/j.seppur.2004.01.005

[34] T. Reemtsma and M. Jekel, "Dissolved Organics in Tannery Wastewaters and Their Alteration by a Combined Anaerobic and Aerobic Treatment," Water Research, Vol. 31, No. 5, 1997, pp. 1035-1046. doi:10.1016/S0043-1354(96)00382-X

[35] G. McKay, H. S. Blair and J. R. Gardner, "Adsorption of Dyes on Chitin. I. Equilibrium Studies," Journal of Applied Polymer Science, Vol. 27, No. 8, 1982, pp. 30433057. doi:10.1002/app.1982.070270827

[36] S. Lagergren, "About the Theory of So-Called Adsorption of Soluble Substances, the Royal Swedish Academy of Sciences," Handlingar, Vol. 24, 1898, pp. 1-39.

[37] Y. S. Ho and G. McKay, "Pseudo-Second Order Model for Sorption Processes," Process Biochemistry, Vol. 34 , No. 5, 1999, pp. 451-465. doi:10.1016/S0032-9592(98)00112-5

[38] P. W. Ramteke, S. Awasthi, T. Srinath and B. Joseph, "Efficiency Assessment of Common Effluent Treatment Plant (CETP) Treating Tannery Effluents," Environmental Monitoring and Assessment, Vol. 169, No. 1-4, 2010, pp. 125-131. doi:10.1007/s10661-009-1156-6.

\section{Nomenclature}

$q=\mathrm{Cr}(\mathrm{III})$ loaded on the resin $(\mathrm{mg} / \mathrm{g}) ;$

$C_{e}=$ Equilibrium concentration of $\mathrm{Cr}(\mathrm{III})(\mathrm{mg} / \mathrm{L})$;

$q_{m}=$ Loading capacity of the resin $(\mathrm{mg} / \mathrm{g})$;

$K_{f}=$ Freundlich Constant;

$n=$ Sorption intensity for Freundlich model;

$K_{l}=$ Langmuir constant;

$q_{t}=$ Adsorption capacity of the resin at time $t(\mathrm{mg} / \mathrm{g})$;

$q_{e}=$ Adsorption capacity of the resin at equilibrium

(mg/g);

$k_{1}=$ First order rate constant $\left(\mathrm{min}^{-1}\right)$. 